\title{
IMPLIKASI HUKUM PEMBEBANAN HAK TANGGUNGAN ATAS TANAH HAK GUNA BANGUNAN \\ DI ATAS TANAH HAK PENGELOLAAN YANG IJIN PEMANFAATAN TANAHNYA DICABUT OLEH GUBERNUR
}

\author{
Oleh
}

\author{
A.A.Ayu Ray Saraswati \\ NIM 1192462022 \\ Mahasiswa Program Magister Kenotariatan Universitas Udayana \\ e-mail:gungraysaras@gmail.com \\ Pembimbing I : Prof. Dr. I Dewa Gede Atmadja,SH.,MS. \\ Pembimbing II : Dr. I Nyoman Suyatna,SH.,MH.
}

\begin{abstract}
Governor as the head of the province has the authority to regulate the allocation and use of assets held by the provincial government, including land management rights. The purpose of management rights titled land is to be given to a third party. This provision is based on the Decree of the Governor in form of land utilization permit. Furthermore, over that given land, the rights of land can be applied above it, for example Building Right Title. Problem that occur is if the Governor as concessionaires strip the utilization permit that has been granted, as in the case of Management Rights Titled Land No.2 with the Building Right Title Land No. 80 on behalf of PT. Abdi Persada Nusantara in Kesiman Petilan Village, Denpasar. What about the legal status of land rights that existed on the management rights titled land and the legal consequences of the burdening the liability right to management rights titled land after the revocation of the land utilization permit.

This type of research in this thesis is a normative legal research, the research that seek answers by examining the problems of legal materials and the use of primary and secondary theoretical foundation as one of the characteristics of a normative study. The approach used in this study is the Regulation Approach, Legal Concepts Analysis Approach and the Case Approach, furthermore the discussion done by descriptive analysis way by describing and analyzing the results obtained from the legal materials, systematically arranged so that the conclusion can be obtained.

Result of study of the prooblems studied is the legal status of land rights on management rights titled land that it's utilization permit has been stripped by the concessionaires became abolished. Abolishment of the land rights led to liability rights does not lead to the abolishment of the secured debt. Receivables creditors still there, but no longer as claims that guaranteed specifically by the special position of the creditor (lender preferred)
\end{abstract}

Keywords : Legal Consequeces, Building Rights Tittle, Management Rights, Land Utilization Permits, Governor.

\section{Pendahuluan}

Bumi, air dan ruang angkasa serta kekayaan alam yang terkandung di dalamnya, sepanjang perjalanan sejarah umat manusia selalu merupakan sumber daya alam yang amat penting untuk kelangsungan hidupnya. Permukaan bumi atau yang disebut Tanah, merupakan salah satu Sumber Daya Agraria atau Sumber Daya Alam. Sebagai sumber kekayaan alam yang terdapat di darat, tanah dapat menjadi salah satu Modal Dasar Pembangunan Nasional. ${ }^{1}$

Penguasaan pemerintah atas tanah lahir dari konsep Hak Menguasai Negara yang secara konstitusional telah diatur di dalam ketentuan Pasal 33 ayat (3) Undang-Undang Dasar Negara Republik Indonesia Tahun 1945 yang kemudian melahirkan

${ }^{1}$ Supriyadi, 2010, Aspek Hukum Tanah Aset Daerah Menemukan Keadilan, Kemanfaatan, dan Kepastian atas Eksistensi Tanah Aset Daerah, PT. Prestasi Pustakaraya, Jakarta, hal.1 
konsep Hak Menguasai Negara atas tanah yang bertujuan untuk kemakmuran rakyat. Pada perkembangannya, guna meningkatkan pembangunan ekonomi Indonesia sebagai bagian dari pembangunan ekonomi nasional dalam upaya mewujudkan kesejahteraan rakyat yang adil dan makmur, pemerintah bekerjasama dengan pihak swasta untuk merealisasikannya. Pemerintah sebagai pihak yang diberikan kewenangan untuk menguasai tanah negara, selain untuk digunakan sendiri juga dapat memberikannya kepada pihak ketiga yang sering disebut sebagai Hak Pengelolaan. Selanjutnya pihak ketiga tersebut dapat memohonkan hak atas tanah lagi di atas tanah hak pengelolaan tersebut misalnya Hak Guna Bangunan.

Ketentuan Pasal 4 ayat (1) Undang-Undang Nomor 4 Tahun 1996 tentang Hak Tanggungan dan penjelasannya, menyatakan bahwa : "Hak atas tanah yang dapat dibebani Hak Tanggungan adalah : Hak Milik; Hak Guna Usaha; Hak Guna Bangunan." Hak Guna Bangunan yang dimaksud meliputi Hak Guna Bangunan di atas tanah Negara, di atas tanah Hak Pengelolaan, maupun di atas tanah Hak Milik. Berdasarkan ketentuan tersebut, menjelaskan bahwa Hak Guna Bangunan di atas tanah Hak Pengelolaan dapat dijadikan jaminan utang dengan dibebani Hak Tanggungan.

Pemberian kredit oleh Bank kepada debitur yang menjadikan tanah hak guna bangunan di atas tanah hak pengelolaan sebagai jaminan kredit didasarkan pada sertipikat hak guna bangunan yang telah dikeluarkan oleh Badan Pertanahan Nasional. Sertipikat tersebut menegaskan bahwa debitur sebagai pihak yang menguasai tanah tersebut dengan tujuan untuk mendirikan bangunan dalam jangka waktu tertentu yang telah disepakati dalam perjanjian penggunaan tanah dengan pemegang hak pengelolaan.

Pemegang hak tanggungan sejatinya telah mendapat kepastian terkait jaminan atas tanah yang diberikan. Apabila nantinya debitur pailit, jaminan yang diberikan tersebut akan dieksekusi atau dilakukan lelang guna pemenuhan kewajiban dari debitur, dan akan diutamakan dalam pemenuhan piutang (kreditur preferen). Permasalahan yang muncul kemudian ialah apabila pemegang hak pengelolaan mencabut ijin pemanfaatan tanah yang merupakan dasar lahirnya hak guna bangunan sebelum berakhirnya jangka waktu penggunaan tanah. Bagaimanakah status hukum dari tanah hak guna bangunan yang dibebani hak tanggungan tersebut serta akibat hukum atas pembebanan hak tanggungan terhadap hak guna bangunan di atas tanah hak pengelolaan tersebut.

Kasus ini terjadi pada tanah Hak Pengelolaan No. 2 dengan Hak Guna Bangunan No. 80 atas nama PT. Abdi Persada Nusantara (APN) di Desa Kesiman Petilan-Denpasar. Tanah dengan sertipikat HPL No.2 tersebut merupakan Aset/inventaris yang dimiliki oleh Pemerintah Provinsi Bali seluas $8.98 \mathrm{Ha}$ tersebut diberikan ijin 
pemanfaatan tanah kepada Perusahaan Daerah Provinsi Daerah Tingkat I Bali dan Koperasi Pegawai Negeri Praja Kantor Gubernur Kepala Daerah Tingkat I Bali guna membuka kesempatan untuk dapat bekerjasama dengan pihak ketiga. Perusahaan Daerah Tingkat I Bali kemudian mengadakan kerjasama berupa perjanjian Bagi Hasil Keuntungan (profit sharing agreement) dengan PT. Abdi Persada Nusantara (selanjutnya disebut PT. APN) dan diberikan hak untuk menggunakan tanah HPL tersebut untuk membangun dan mengusahakan taman rekreasi.

PT. APN yang telah memiliki Hak Guna Bangunan dengan sertipikat HGB No. 80, selanjutnya membebankan hak tanggungan atas HGB tersebut kepada PT. Bank Negara Indonesia tanpa adanya persetujuan tertulis Pemegang Hak Pengelolaan, dalam hal ini Pemerintah Provinsi Bali. Oleh karena alasan di atas dan karena PT. APN tidak memenuhi perjanjian yang telah disepakati, salah satunya memberikan kontribusi kepada Pemerintah Provinsi Bali sebagai pemilik aset, maka Gubernur Bali mengeluarkan keputusan mencabut ijin pemanfaatan tanah inventaris tersebut.

Dicabutnya ijin pemanfaatan tanah hak pengelolaan menyebabkan hilangnya alas hak atau dasar dari lahirnya Hak Guna Bangunan sebelum berakhirnya jangka waktu pemberian hak atas tanah. Keadaan ini kemudian berpengaruh pada status hukum hak guna bangunan serta pembebanan hak tanggungan atas Hak Guna Bangunan tersebut. Apabila nantinya terjadi wanprestasi dan debitur tidak dapat melunasi hutangnya, bagaimana pihak bank sebagai kreditur pemegang hak tanggungan atas hak guna bangunan melakukan guna mendapatkan pengembalian piutangnya, dikarenakan ijin pemanfaatan tanah hak pengelolaan sebagai alas hak atau dasar untuk lahirnya Hak Guna Bangunan telah dicabut oleh pemegang Hak Pengelolaan.

Berdasarkan uraian di atas serta masalah yang muncul, belum ada aturan hukum yang mengatur mengenai pencabutan ijin pemanfaatan tanah hak pengelolaan yang diatasnya telah diberikan hak atas tanah berupa hak guna bangunan dan kemudian dibebani dengan hak tanggungan. Hal ini terkait dengan status hukum hak guna bangunan yang dibebankan hak tanggungan dan juga akibat hukum terhadap hak tanggungan yang berada di atas tanah hak guna bangunan pasca dicabutnya ijin pemanfaatan tanah hak pengelolaan oleh pemegangnya.

Beberapa peraturan perundangundangan memang mengatur mengenai Pembebanan hak Tanggungan atas Hak Guna Bangunan di atas Tanah Hak Pengelolaan, namun tidak mengatur secara jelas dan rinci terkait dengan kibat yang ditimbulkan apabila ijin pemanfaatan tanah hak pengelolaan yang menjadi dasar pemberian Hak Guna Bangunan dicabut oleh pemegang Hak Pengeloalaan. Khususnya mengenai status hukum Hak Guna Bangunan tersebut dan akibat hukum terhadap hak tanggungan yang dibebankan pada Hak 
Guna Bangunan di atas tanah Hak Pengelolaan belum ada aturan hukum yang secara jelas menentukan mengenai hal ini. Dengan demikian, telah terjadi kekosongan norma. Inilah kemudian yang menjadi alasan penulis merasa tertarik untuk melakukan penelitian ini dengan judul: "Implikasi Hukum Pembebanan Hak Tanggungan Atas Tanah Hak Guna Bangunan di atas tanah Hak Pengelolaan Yang Ijin Pemanfaatan Tanahnya Dicabut Oleh Gubernur".

Adapun tujuan umum yang ingin dicapai dari penelitian ini adalah untuk mengetahui implikasi atau akibat hukum dari dicabutnya ijin pemanfaatan tanah Hak pengelolaan yang diatasnya terdapat hak atas tanah (Hak Guna Bangunan) yang sedang dibebani Hak Tanggungan. Sedangkan tujuan khusus yang ingin dicapai terkait dengan permasalahan yang akan dijawab yakni untuk mengetahui status hukum dari Hak Guna Bangunan di atas tanah Hak Pengelolaan dan akibat hukum dari Hak Tanggungan yang berada di atas tanah Hak Pengelolaan pasca dicabutnya ijin pemanfaatan tanah oleh Gubernur.

\section{Metode Penelitian}

\subsection{Jenis Penelitian}

Jenis penelitian yang digunakan pada tesis ini adalah dengan memakai jenis penelitian hukum normatif. Dalam penelitian ini terdapat isu hukum yang beranjak dari adanya kekosongan norma hukum terhadap suatu peristiwa konkret tertentu yang perlu dicari jawaban atau jalan keluar dari permasalahan yang terjadi. Jawaban tersebut didapat dari menggunakan bahan-bahan hukum yang terdiri atas bahan hukum primer dan bahan hukum sekunder.

\subsection{Jenis Pendekatan}

Penelitian pada tesis ini dilakukan melalui pendekatan perundangundangan (statute approach), pendekatan Analisis Konsep Hukum (analitical \& conseptual approach) dan pendekatan kasus (The case approach).

\subsection{Sumber bahan hukum}

Sumber bahan hukum dalam penelitian ini berasal dari penelitian kepustakan (library research). Bahan hukum primer yang digunakan adalah berbagai Peraturan Perundangundangan yang terkait dengan masalah yang diteliti, yakni Peraturan perundang-undangan terkait dengan Hukum Perdata, Hukukum Administrasi, dan Hukum Pertanahan ; Selanjutnya, bahan hukum sekunder yang digunakan untuk membahas/menjelaskan bahan hukum primer, antara lain: buku-buku (literature), artikel, makalah/jurnal, tesis, desertasi; Kamus Bahasa Indonesia, Bahasa Belanda dan Bahasa Inggris digunakan pula dalam penelitian ini sebagai bahan hukum tertier.

\subsection{Teknik Pengumpulan Bahan Hukum}

Teknik pengumpulan bahan hukum yang digunakan adalah studi kepustakaan. Peneliti melakukan penelitian terhadap berbagai dokumen dan bahan-bahan hukum pustaka yang terkait dengan permasalahan yang diteliti. Bahan hukum yang diperoleh selanjutnya dicatat pada kartu-kartu. Pada kartu juga dicatat sumber dari 
mana data tersebut diperoleh nama pengarang/penulis, judul buku atau artikel, halaman. Kartu-kartu tersebut disusun berdasarkan pokok bahasan dan pada kartu juga dicatat mengenai konsep-konsep dan asas-asas hukum yang ada hubungannya dengan penelitian.

\subsection{Analisa Bahan Hukum}

Teknik analisis bahan hukum yang digunakan dalam penelitian ini adalah teknik deskripsi, teknik evaluasi, teknik argumentasi dan teknik sistematisasi. Diawali dengan pengumpulan bahan-bahan hukum untuk selanjutnya diklasifikasikan. Hasil klasifikasi tersebut selanjutnya disistematisasi. Proposisi, pandangan, pernyataan rumusan norma, yang terdapat dalam bahan hukum tersebut selanjutnya oleh penulis dievaluasi, kemudian diberi argumentasi. Bahan hukum yang telah disistematisasi tersebut kemudian dianalisis dengan teori-teori yang relevan maupun konsep-konsep guna menjawab permasalahan yang diteliti, selanjutnya hasil tersebut dijadikan dasar dalam mengambil kesimpulan.

\section{Perjanjian Kredit Menurut Hukum} Perdata atas Hak Guna Bangunan di atas Tanah Hak Pengelolaan

Perjanjian merupakan salah satu sumber perikatan. Selain perjanjian, sumber perikatan lainnya adalah undang-undang dan perjanjianperjanjian tertentu. Sebagai sumber perikatan maka segala ketentuan tentang perjanjian menjadi syarat perikatan karena perjanjian. Pasal 1313 BW memberikan rumusan pengertian perjanjian yaitu: "suatu perbuatan dengan mana satu orang atau lebih mengikatkan dirinya terhadap satu orang lain atau lebih. Subekti, memberi difinisi perjanjian adalah suatu peristiwa dimana seorang berjanji pada seorang lain atau di mana dua orang itu saling berjanji untuk melaksanakan sesuatu hal. ${ }^{2}$

Perjanjian kredit merupakan salah satu contoh perjanjian. Sebagai bagian dari perjanjian, aturan hukum yang mengatur perjanjian juga mengatur perjanjian kredit. Sebelum membahas mengenai pengertian perjanjian kredit, terlebih dahulu diberikan pengertian dari kredit. Kata kredit berasal dari Bahasa Romawi, yakni credere yang artinya percaya, bila dihubungkan dengan bank maka terkandung pengertian bahwa bank sebagai kreditor percaya meminjamkan uang kepada debitur, karena dibitur dapat dipercaya kemampuannya untuk membayar lunas pinjamannya setelah jangka waktu yang ditentukan. ${ }^{3}$ Istilah credere selanjutnya menjadi Kredit (bahasa Indonesia) yang mempunyai arti kepercayaan. Seseorang yang memperoleh kredit berarti memperoleh kepercayaan, dengan kata lain kepercayaan adalah dasar dari kredit. ${ }^{4}$

Pasal 1 angka 11 Undang-Undang Nomor 10 Tahun 1998 tentang Perbankan menentukan pengertian kredit, yaitu: "penyediaan uang atau tagihan bedasarkan persetujuan atau kesepakatan pinjam meminjam antara

2 Subekti, 1996, Hukum Perjanjian, Intermasa, Jakarta, hal. 1.

${ }^{3}$ Gatot Supramono, 1996, Perbankan dan Masalah Kredit Suatu Tinjauan Yuridis, Djambatan, Jakarta, hal. 44.

4 Sidharta P. Soerjadi dalam Adrian Sutedi, 2010, Hukum Hak Tanggungan, Sinar Grafika, Jakarta, hal. 19 
bank dengan pihak lain yang mewajibkan pihak peminjam untuk melunasi hutangnya setelah jangka waktu tertentu dengan jumlah bunga, imbalan atau pembagian hasil keuntungan”. Dari pengertian tersebut, selanjutnya didapatkan dua aspek yang terkandung, yaitu aspek yuridis dan aspek ekonomis. Aspek yuridis dilihat dari adanya dua pihak yang saling mengikatkan diri dalam suatu perjanjian dimana masingmasing pihak mempunyai hak dan kewajiban. Sedangkan aspek ekonomis, dilihat dari adanya pembayaran bunga yang diterima kreditur sebagai keuntungan.

Mariam Darus Badrulzaman memberikan pengertian perjanjian kredit sebagai penyediaan uang atau tagihann yang dapat dipersamakan dengan itu, berdasarkan persetujuan atau kesepakatan pinjam meminjam antara bank dan pihak lain yang mewajibkan pihak penerima pinjaman melunasi utangnya setelah jangka waktu tertentu dengan jumlah bunga, imbalan atau pembagian hasil keuntungan. ${ }^{5}$ Selanjutnya, Adrian Sutredi memberikan pengertian perjanjian kredit sebagai persetujuan atau kesepakatan pinjam-meminjam antara bank dengan pihak lain (debitur) dengan syarat-syarat dan kewajiban tertentu yang harus dipenuhi disebut perjanjian kredit.

Berdasarkan pendapat para sarjana dan dari pengertian kredit dalam Pasal 1 butir 11 Undang-Undang Perbankan,

${ }^{5}$ Mariam Darus Badrulzaman, 1987, Babbab Tentang Creditverband, Gadai dan Fiducia cetakan IV, Alumni, Bandung, hal. 34 dapat ditentukan unsur-unsur yang terdapat dalam kredit, yaitu:

a. Adanya kepercayaan, yaitu keyakinan dari pemberi kredit (kreditur) bahwa pada masa yang akan datang, debitur akan mengembalikan prestasi (uang) yang diberikan kepadanya.

b. Adanya waktu, yaitu jangka waktu untuk pengembalian yang telah disetujui antara para pihak.

c. Adanya prestasi, yang dimaksud prestasi dalam kredit ini ialah uang.

d. Adanya resiko, yaitu kemungkinan kerugian yang diterima oleh pemberi kredit

e. Adanya jaminan, untuk mengantisipasi resiko yang mungkin timbul. Jaminan ini berguna sebagai upaya akhir bila debitur wanprestasi. ${ }^{6}$

Jaminan dalam pemberian kredit dimaksudkan untuk memberi keyakinan kepada bank atau kreditur bahwa ia akan mendapatkan kembali uang yang diberikannya kepada debitur. Hal ini telah diatur dalam ketentuan Pasall 1131 dan 1132 BW. Jaminan memberikan kepastian hukum bagi kreditur untuk menerima pengembalian pokok kredit dan bunga dari debitur, sedangkan bagi debitur dengan modal yang diberikan memberikan kepastian dalam berusaha. Pemberian jaminan berdasarkan perjanjian yang merupakan perikatan antara kreditur dengan debitur atau pihak ketiga yang isinya menjamin pelunasan utang yang timbul dari pemberian kredit. ${ }^{7}$

Perjanjian jaminan ini bersifat accessoir yaitu selalu mengikuti atau dikaitkan dengan

${ }^{6}$ Hassanudin Rahman, 1998, Aspek-Aspek Hukum Pemberian Kredit Perbankan di Indonesia, Citra Aditya Bakti, Bandung, hal. 96.

${ }^{7}$ Adrian Sutedi, op.cit, hal. 25. 
perjanjian pokok yang bersifat principal ${ }^{8}$ Tanpa adanya perjanjian kredit, perjanjian jaminan kredit tidak akan ada. Kedudukan perjanjian kredit adalah perjanjian pokok (principal), sedangkan kedudukan perjanjian jaminan kredit disebut sebagai perjanjian tambahan atau ikutan (accesoir).

Dilihat dari bentuknya, perjanjian kredit merupakan perjanjian baku atau perjanjian standar, karena dalam praktik perbankan setiap bank telah menyediakan blanko atau formulir perjanjian kredit yang isinya telah dipersiapkan terlebih dahulu. Formulir tersebut diberikan kepada setiap calon nasabah dan diminta pendapatnya apakah dapat menerima syarat yang tercantum dalam formulir atau tidak. ${ }^{9}$ Apabila debitur menerima ketentuan dan persyaratan tersebut maka debitur wajib untuk menandatangani perjanjian kredit, sebaliknya apabila debitur menolak dan tidak setuju maka ia tidak perlu menandatangani. Dalam hal ini debitur tidak memiliki posisi tawar dan tidak diberi kesempatan untuk turut menentukan isi maupun klausula dari perjanjian kredit tersebut, sebagai konsekuensi dari bentuk perjanjian baku.

Guna memberikan kepastian dan perlindungan hukum bagi kreditur dan debitur, akta perjanjian kredit dalam dunia perbankan dibuat dalam bentuk akta otentik. Disinilah peran dari Notaris diperlukan yaitu untuk memenuhi syarat akta otentik dibuat oleh dan dihadapan pejabat yang berwenang. Akta otentik tersebut berfungsi sebagai alat bukti yang sempurna karena meliputi pembuktian lahiriah, formil, dan materiil. Peran Notaris yang lain terkait dengan tugasnya memberikan

${ }^{8}$ Sri Soedewi Masjchoen Sofwan,1981, Hukum Perdata, Hak Jaminan Atas Tanah, Liberty, Yogyakarta, hal 38.

${ }^{9}$ Johannes Ibrahim,2004, Cross Default dan Cross Collateral sebagai Upaya Penyelesaian Kredit Bermasalah, PT Refika Aditama, Bandung, hal. 30 penyuluhan hukum maupun solusi bagi kedua belah pihak, dan memastikan bahwa masingmasing pihak memahami dan mengerti isi dari akta perjanjian tersebut.

Pasal 1868 KUHPerdata memberikan pengertian akta otentik, yaitu: "akta yang dibuat dalam bentuk yang ditentukan oleh undangundang, dibuat oleh atau di hadapan pegawaipegawai umum yang berkuasa untuk itu ditempat dimana akta dibuatnya". Berdasarkan pengertian tersebut, yang dimaksud akta otentik harus memenuhi kriteria sebagai berikut: 1) bentuknya ditentukan dan sesuai dengan Undang-Undang; 2) dibuat oleh atau di hadapan pejabat umum; dan 3) pejabat umum tersebut harus berwenang untuk membuat akta tersebut. Dari segi pembuktiannya akta otentik merupakan alat bukti yang sempurna.

Perjanjian kredit biasanya disertai dengan jaminan. Jaminan tersebut dapat berupa hak atas tanah misalnya Hak Guna Bangunan. Jaminan tersebut masuk dalam golongan jaminan kebendaan, yaitu Hak Tanggungan. Hak Guna Bangunan termasuk dalam salah satu hak atas tanah yang dapat dibebani Hak Tanggungan. Selanjutnya berdasarkan ketentuan Pasal 21 PP No.40 Tahun 1996, Hak Guna Bangunan berdasarkan asal tanahnya dapat diberikan pada tanah-tanah yaitu: 1) Di atas tanah yang dikuasai langsung oleh Negara; 2) di atas tanah Hak Pengelolaan; 3) Di atas tanah Hak Milik.

Hak Guna Bangunan di atas tanah Hak Pengelolaan terjadi dengan keputusan pemberian hak atas usul pemegang Hak Pengelolaan, yang diterbitkan oleh Badan Pertanahan Nasional berdasarkan Pasal 4 Permen Agraria/Kepala BPN No. 3 Tahun 1999, yang diubah oleh Pasal 4 Peraturan Kepala Badan Pertanahan Nasional Republik Indonesia No. 1 Tahun 2011. Prosedur terjadinya Hak Guna Bangunan ini diatur dalam 
Permen Agraria/Kepala BPN No. 9 Tahun 1999.

IV. Status Hukum Tanah Hak Guna Bangunan Dengan Beban Hak Tanggungan di Atas Tanah Hak Pengelolaan yang Ijinnya Dicabut Oleh Gubernur

4.1. Penyerahan Penggunaan Bagian Tanah Hak Pengelolaan dan Pemberian Hak Guna bangunan di atas Tanah Hak Pengelolaan

Berdasarkan ketentuan Pasal 6 ayat (1) Peraturan Menteri Agraria No. 9 Tahun 1965 jo Pasal 2 Peraturan Menteri Dalam Negeri No. 1 Tahun 1977, Pemegang Hak Pengelolaan memiliki wewenang yang salah satunya adalah kewenangan untuk menyerahkan bagian-bagian tanah Hak Pengelolaan kepada pihak ketiga. Hak atas tanah yang dimaksud ialah Hak Milik, Hak Guna Bangunan, atau Hak Pakai.

Subjek Pemegang Hak Atas Tanah di atas Tanah Hak Pengelolaan ialah pihak ketiga. Pihak ketiga tersebut ialah pihak yang nantinya diberi kewenangan untuk menggunakan tanah hak pengelolaan dengan hak atas tanah yang didasarkan pada penyerahan bagian tanah hak pengelolaan harus memenuhi persyaratan subjektif sebagai pemohon dan pemegang hak atas tanah sebagaimana diatur dalam peraturan perundang-undangan yang berlaku.

Apabila hak atas tanah yang dimohonkan adalah Hak Guna Bangunan, maka yang dapat mengajukan permohonan adalah seorang Warga Negara Indonesia atau badan hukum yang didirikan menurut hukum Indonesia dan berkedudukan di wilayah Indonesia sebagaimana diatur dalam pasal 36 ayat (1) UUPA jo Pasal 19 Peraturan Pemerintah No. 40 Tahun 1996. Berbeda halnya dengan Hak Pakai, selain Warga Negara Indonesia atau Badan Hukum yang didirikan menurut hukum Indonesia, orang perorangan berkewarganegaraan asing atau badan hukum asing yang memiliki perwakilan di Indonesia dapat mengajukan permohonan Hak Pakai di atas Tanah Negara saja dan tidak boleh menjadi pemegang Hak Pakai di atas tanah Hak Pengelolaan maupun di atas Tanah Hak Milik.

Prosedur pemberian hak atas tanah di atas Tanah Hak Pengelolaan dilakukan sesuai dengan Peraturan Menteri Negara Agraria/Kepala Badan Pertanahan Nasional No. 9 Tahun 1999 tentang Tata Cara Pemberian dan Pembatalan Hak Atas Tanah Negara dan Hak Pengelolaan. Untuk lebih jelasnya penyerahan penggunaan bagian Tanah Hak Pengelolaan kepada pihak ketiga dilakukan melalui 3 tahapan sebagai berikut ${ }^{10}$ :

1. Tahap Pembuatan Perjanjian

2. Tahap Pemberian Hak Atas Tanah di atas Hak Pengelolaan

3. Tahap Penerbitan Sertipikat

1. Tahap Pembuatan Perjanjian

Sebelum pemberian hak atas tanah dilakukan oleh pihak yang berwenang cq Kepala Kantor Pertanahan Kabupaten/Kota setempat, pihak ketiga yang akan menerima bagian tanah Hak Pengelolaan wajib memperoleh persetujuan terlebih dahulu dari pemegang Hak Pengelolaan, yaitu berupa pembuatan perjanjian penyerahan penggunaan bagian tanah Hak Pengelolaan antara pihak ketiga sebagai calon pengguna tanah dengan pemegang Hak Pengelolaan. Mengenai bentuk dari perjanjian ini memang tidak ada ketentuan yang mengaturnya, hal ini sebagai wujud penghormatan asas kebebasan

${ }^{10}$ Irawan Soerodjo, 2014, Hukum Pertanahan Hak Pengelolaan atas Tanah, LaksBang Mediatama, Yogyakarta, hal. 92. 
berkontrak Pasal 1338 KUHPerdata. Para pihak dalam perjanjian diberi kebebasan untuk membuat kesepakatan sepanjang tidak bertentangan dengan kepatutan, kesusilaan dan ketentuan hukum yang berlaku.

2. Tahap Pemberian Hak Atas Tanah di atas Hak Pengelolaan

$$
\text { Pada tahap ini peran dan }
$$
wewenang pemegang Hak Pengelolaan ialah menyerahkan penggunaan tanah dan mengusulkan pemberian haknya kepada pejabat yang berwenang. Untuk pemberian hak atas tanah di atas tanah Hak Pengelolaan merupakan tugas dan wewenang penuh Kepala Kantor Pertanahan Kabupaten/Kota sebagaimana diatur dalam peraturan Menteri Negara Agraria/Kepala Badan Pertanahan Nasional No. 3 Tahun 1999 tentang Pelimpahan Kewenangan Pemberian dan Pembatalan Keputusan Pemberian Hak Atas Tanah Negara yang sebagian telah diubah dengan Peraturan Kepala Badan Pertanahan Nasional No. 1 Tahun 2011 tentang Pelimpahan Kewenangan Pemberian Hak Atas Tanah dan Kegiatan Pendaftaran Tanah Tertentu.

Pemberian hak atas tanah kepada pihak ketiga ditentukan dari isi kesepakatan dalam perjanjian. Ada tiga jenis hak atas tanah yang dapat diberikan, yaitu Hak Milik, Hak Guna Bangunan atau Hak Pakai. Berdasarkan permohonan dan perjanjian tersebut berserta beberapa berkas penunjang lainnya, Kepala Kantor Pertanahan Kabupaten/Kota menerbitkan Surat Keputusan Pemberian Hak atas Tanah (SKPH) atas nama pemohon. Penerbitan SKPH ini bukan saat lahirnya hak atas tanah di atas tanah Hak Pengelolaan.

3. Tahap Penerbitan Sertipikat

Setelah semua syarat terpenuhi dan berdasarkan wewenang yang dimiliki, Kepala Kantor Pertanahan Kabupaten/Kota menerbitkan sertipikat hak atas tanah, dan memberikannya kepada yang bersangkutan (pemohon/pihak ketiga) sebagai tanda bukti hak. Saat lahir/terbitnya sertipikat yang dilakukan oleh Kepala Kantor Pertanahan Kabupaten/Kota merupakan saat lahirnya hak dan wewenang bagi pihak ketiga (investor) untuk menggunakan/memanfaatkan dan mengelola bagian tanah hak pengelolaan tersebut.

Pihak ketiga yang memperoleh hak atas tanah dalam penggunaan atau pemanfaatan tanah tidak boleh bertentangan dengan perjanjian penyerahan bagian tanah hak pengelolaan (SPPT) dan peruntukan tanah yang telah ditetapkan, baik oleh Pemegang Hak Pengelolaan maupun ditetapkan oleh pemerintah daerah setempat sesuai dengan Rencana Tata Ruang Wilayah (RTRW) atau Rencana Detail Tata Ruang (RDTL).

4.2. Wewenang Gubernur Dalam Penguasaan Dan Pengelolaan Tanah Hak Pengelolaan

Gubernur sebagai kepala daerah propinsi memiliki wewenang untuk mengurusi urusan bidang pertanahan sebagai bentuk delegasi 
kewenangan dari Pemerintah Pusat yang merupakan pelaksanaan otonomi daerah. Pelimpahan wewenang oleh pemerintah kepada Gubernur, Bupati/Walikota untuk menjalankan fungsi-fungsi terinci disebut dengan dekonsentrasi. Pada dekonsentrasi tersebut wewenang untuk mengurus dilimpahkan oleh pemerintah pusat, tetapi wewenang pengaturannya masih tetap di tangan mereka. ${ }^{11}$ Wewenang tersebut salah satunya adalah pemberian ijin pemanfaatan tanah hak pengelolaan yang tujuannya memang diperuntukkan untuk pihak ketiga. Ijin pemanfaatan tanah hak pengelolaan, merupakan keputusan yang dikeluarkan pejabat daerah (Gubernur) sebagai pemegang hak pengelolaan. Keputusan yang dikeluarkan oleh pejabat daerah termasuk dalam Surat Keputusan Tata Usaha Negara. Pasal 1 angka 9 Undang-Undang No. 5 Tahun 1986 tentang Peradilan Tata Usaha Negara sebagaimana telah diubah dengan Undang-Undang No. 9 Tahun 2004 tentang Perubahan atas Undang-Undang No. 5 Tahun 1986 dan terakhir dengan Undang-Undang No. 51 Tahun 2009 tentang Perubahan Kedua Atas Undang-Undang No. 5 Tahun 1986 tentang Peradilan Tata Usaha Negara, menentukan:

Keputusan Tata Usaha Negara adalah suatu penetapan tertulis yang dikeluarkan oleh badan atau pejabat tata usaha negara yang berisi tindakan hukum tata usaha negara yang berdasarkan peraturan perundang-undangan yang berlaku, yang bersifat konkret, individual, dan final yang menimbulkan akibat hukum bagi seseorang atau badan hukum perdata.

Indroharto mengatakan bahwa "suatu penetapan tertulis (beschikking) itu selalu merupakan salah satu bentuk dari Keputusan Badan atau Jabatan Tata Usaha Negara yang

${ }^{11}$ Arie Sukanti Hutagalung, Markus Gunawan, 2008,Kewenangan Pemerintah di Bidang Pertanahan, PT. Raja Grafindo Persada, Jakarta, hal. 109. merupakan suatu tindakan hukum Tata Usaha Negara (administratieve rechtschandeling) ${ }^{12}$

Sebagai pemegang hak pengelolaan, Gubernur memiliki wewenang untuk memberikan ijin maupun mencabut. Pencabutan ijin ini dilakukan sebagai salah satu bentuk pengawasan dan kontrol yang dilakukan oleh Gubernur dalam hal terjadinya penyimpangan yang dilakukan oleh pihak ketiga pemegang hak atas tanah (HGB) di atas ttanah hak pengelolaan. Penyimpangan yang dimaksud ialah bila dalam pelaksanaannya tidak lagi sesuai dengan Surat Perjanjian Pemanfaatan Tanah (SPPT) dan mengakibatkan kerugian bagi daerah.

4.3. Kedudukan Hukum Tanah Hak Guna Bangunan di atas Tanah Hak Pengelolaan yang ijin pemanfaatan tanahnya telah dicabut oleh Gubernur

Dicabutnya surat ijin pemanfaatan tanah hak pengelolaan oleh pemegangnya sebelum jangka waktu berakhir, memberikan konsekuensi pada status hukum hak guna bangunan yang berada di atasnya. Pencabutan ijin yang dilakukan oleh Gubernur tidak serta merta menghapus hak atas tanah (Hak Guna Bangunan) di atas Hak Pengelolaan. Apabila berdasarkan pengawasan yang dilakukan oleh Gubernur telah terjadi penyimpangan yang berakibat pada kerugian bagi pemegang Hak Pengelolaan, maka Gubernur dapat mengusulkan pemerintah cq. Kepala Kantor Pertanahan yang berwenang untuk membatalkan sertipikat hak atas tanah. Pembatalan hak atas tanah tersebut memberi konsekuensi pada hapusnya hak atas tanah. Hapusnya hak atas tanah menyebabkan tanah tersebut tidak lagi berstatus atau berkedudukan sebagai Hak Guna Bangunan atau dengan kata lain Hak Guna Bangunan menjadi hapus.

${ }^{12}$ Indroharto, 1995, Perbuatan Pemerintahan Menurut Hukum Publik dan Hukum Perdata, LPP-HAN, Jakarta, hal. 117 
Faktor-faktor penyebab hapusnya Hak Guna Bangunan dijabarkan dalam Pasal 35 Peraturan Pemerintah No. 40 tahun 1996, yaitu sebagai berikut:

1) Berakhirnya jangka waktu yang ditetapkan dalam keputusan pemberian atau perpanjangan atau dalam perjanjian pemberiannya;

2) Dibatalkan oleh pejabat yang berwenang, pemegang hak pengelolaan atau pemegang Hak Milik sebelum jangka waktunya berakhir, karena:

(a) Tidak dipenuhinya kewajibankewajiban pemegang dan/atau dilanggarnya ketentuan-ketentuan dalam Hak Guna Bangunan;

(b) Tidak dipenuhinya syarat-syarat atau kewajiban-kewajiban yang tertuang dalam perjanjian pemberian Hak Guna bangunan antara pemegang Hak Guna Bangunan dengan pemilik tanah atau perjanjian penggunaan tanah Hak Pengelolaan (garis bawah penulis);

(c) Putusan pengadilan yang mempunyai kekuatan hukum tetap.

3) Dilepaskan secara sukarela oleh pemegang haknya sebelum jangka waktunya berakhir;

4) Hak Guna Bangunannya dicabut;

5) Ditelantarkan;

6) Tanahnya musnah;

7) Pemegang Hak Guna Bangunan tidak memenuhi syarat sebagai pemegang Hak Guna Bangunan.

Hapusnya Hak Guna Bangunan atas tanah Hak Pengelolaan, berdasarkan ketentuan Pasal 36 Peraturan Pemerintah No. 40 Tahun 1995 mengakibatkan tanahnya kembali ke dalam penguasaan pemegang Hak Pengelolaan. Selanjutnya, Pasal 38 Peraturan Pemerintah No. 40 Tahun 1995 melahirkan kewajiban bagi bekas pemegang Hak Guna Bangunan untuk menyerahkan tanahnya kepada pemegang Hak Pengelolaan dan memenuhi ketentuan yang sudah disepakati dalam perjanjian penggunaan tanah Hak Pengelolaan. Segala perbuatan hukum yang dilakukan pada hak atas tanah tersebut termasuk perikatan yang timbul di atasnya menjadi batal demi hukum. Batal demi hukum (null and void) merupakan salah satu pembatalan yang memiliki konsekuensi yuridis bahwa sejak awal perjanjian atau perikatan itu dianggap tidak pernah ada. ${ }^{13}$

V. Kedudukan Hukum Atas Alas Hak/Title Hak Guna Bangunan Dengan Beban Hak Tanggungan di atas Tanah Hak Pengelolaan yang ijinnya Dicabut Oleh Gubernur

5.1. Pembebanan Hak Tanggungan Terhadap Tanah Hak Guna Bangunan di atas tanah Hak Pengelolaan

Hak Guna Bangunan sebagai salah satu jenis hak atas tanah memiliki sifat yang dapat dijadikan jaminan utang dengan dibebani Hak Tanggungan. Prosedur pembebanan Hak Tanggungan pada Hak Guna Bangunan di atas tanah Hak Pengelolaan pada dasarnya sama dengan prosedur pembebanan Hak Tanggungan pada Hak Guna Bangunan pada umumnya, yaitu diawali dengan mengajukan permohonan kredit dengan mengisi formulir permohonan kredit yang telah disediakan oleh pihak bank. Selanjutnya pihak bank menganalisis dan dilakukan evaluasi kredit yang digunakan sebagai dasar pertimbangan diterima atau ditolaknya permohonan kredit. Apabila pihak bank menyatakan layak dilanjutkan dengan negoisasi hingga terjadi kesepakatan antara kedua belah pihak yang ditandai dengan penandatanganan perjanjian kredityang berupa surat pengakuan utang dengan pengikatan jaminan (berupa jaminan hak tanggungan) dihadapan Pejabat Pembuat Akta Tanah (PPAT) dan pejabat Bank. Setelah dilakukan pengikatan jaminan Hak Tanggungan, calon debitor dinyatakan telah memenuhi persyaratan, kemudian bank merealisasikan kredit kepada calon debitur. $^{14}$

${ }^{13}$ Bung Pokrol, Batalnya Suatu Perjanjian, Hukum online, http: hukumonline.com diakses tanggal 15 Oktober 2014.

${ }^{14}$ Thomas Suyatno, 1993, Dasar-Dasar Hukum Perkreditan Edisi Ketiga, Gramedia Pustaka Utama, Jakarta, hal. 32 
Pengikatan jaminan Hak Tanggungan yang dilakukan dalam perjanjian kredit adalah melalui proses pembebanan Hak Tanggungan. Pembebanan Hak Tanggungan ditentukan berdasarkan ketentuan Pasal 10 s/d Pasal 15 Undang-Undang Hak Tanggungan dan untuk pelaksanaannya diatur dalam Pasal 114 s/d Pasal 119 Peraturan Menteri Negara Agraria/Kepala Badan Pertanahan Nasional No. 3 Tahun 1997. Adapun prosedur pembebanan Hak Tanggungan dilaksanakan melalui tahapan sebagai berikut:

1. Pemberian Hak Tanggungan dengan dibuatnya APHT oleh Pejabat Pembuat Akta Tanah (PPAT), yang didahului dengan perjanjian utang piutang yang dijamin.

2. Pendaftaran APHT kepada Kepala Kantor Pertanahan Kabupaten/Kota setempat untuk dicatat dalam Buku Tanah dan diterbitkan Sertipikat Hak Tanggungan. Pendaftaran ini merupakan saat lahirnya Hak Tanggungan yang dibebankan.

PPAT memiliki peran yang penting dalam pembebanan Hak Tanggungan, karena PPAT merupakan pejabat yang berwenang dalam pembuatan akta pemberian hak tanggungan, sehingga pemberian hak tanggungan tersebut dapat menjadi perbuatan hukum yang sah dengan dibuatkan akta otentik. Akta otentik berupa Akta Pemberian Hak Tanggungan (APHT) ini dapat memberikan kepastian dan perlindungan hukum bagi para pihak (Pemberi dan Penerima Hak Tanggungan).

5.2. Akibat Hukum Pembebanan Hak Tanggungan atas Hak Guna Bangunan Di Atas Tanah Hak Pengelolaan Yang Ijin Pemanfaatan Tanahnya dicabut Oleh Gubernur

Terhadap tanah Hak Guna Bangunan yang berada di atas tanah Hak Pengelolaan yang ijin pemanfaatannya telah dicabut oleh Gubernur, memberi akibat hapusnya status hak guna bangunan pada tanah tersebut. Hapusnya hak atas tanah menyebabkan hapusnya hapusnya hak tanggungan, hal ini berdasarkan pada ketentuan Pasal 18 Undang-Undang Hak Tanggungan, yang menentukan bahwa hapusnya hak tanggungan karena: 1) hapusnya utang yang dijamin hak tanggungan; 2) dilepaskannya hak tanggungan oleh kreditur pemegang hak tanggungan yang dinyatakan dengan akta yang diberikan kepada pemberi hak tanggungan; 3) pembersihan hak tanggungan berdasarkan penetapan Ketua Pengadilan Negeri atas permohonan pembeli objek hak tanggungan, jika hasil penjualan objek hak tanggungan tidak cukup untuk melunasi semua utang debitur; 4) hapusnya hak atas tanah yang dibebani Hak Tanggungan.

Hapusnya hak tanggungan karena hapusnya hak atas tanah yang dibebani hak tannggungan tidak menyebabkan hapusnya utang yang dijamin. Piutang kreditur masih tetap ada, tetapi bukan lagi piutang yang dijamin secara khusus berdasarkan kedudukan istimewa kreditur. Artinya kedudukan krediturnya berubah menjadi kreditur biasa/konkuren (Pasal 1131 jo. Pasal 1132 BW). Hak atas tanah dapat hapus karena hal-hal dalam Pasal 27, 34, dan 40 UUPA atau peraturan perundang-undangan lainnya. Salah satu hal tersebut adalah karena pencabutan ijin pemanfaatan tanah oleh pejabat yang berwenang dengan alasan tidak dipenuhinya syarat atau kewajiban yang tertuang dalam perjanjian penggunaan tanah hak pengeloaan. Pendaftaran hapusnya hak tanggungan yang disebabkan oleh hapusnya hak yang dibebani Hak Tanggungan dilakukan oleh Kepala Kantor Pertanahan karena jabatannya berdasarkan keputusan dari pejabat yang berwenang mengenai pembatalan atau pencabutan hak yang bersangkutan. Hal ini diatur dalam Pasal 
122 ayat (4) Peraturan Menteri Negara Agraria No. 3 Tahun 1997.

Hapusnya Hak Tanggungan mempunyai akibat hukum terhadap kedudukan kreditor pemegang Hak Tanggungan yaitu berubah posisinya dari yang semula menjadi kreditor preferen sebagai pemegang jaminan kebendaan (memiliki kedudukan yang diutamakan dalam pelunasan piutang) menjadi kreditor konkuren yang mempunyai hak perseorangan (hak yang timbul dari jaminan umum atau jaminan yang timbul dari undang-undang sebagaimana tercantum dalam Pasal $1131 \mathrm{BW})$. Walaupun perjanjian kredit utang piutang antara kreditur dan debitur tetap ada (tetap berlangsung), tetapi kedudukan kreditur sebagai pemegang hak tanggungan yang sebelumnya didahulukan dalam pelunasan utangnya (kreditur preferen) menjadi berubah statusnya menjadi kreditur konkuren. ${ }^{15}$ Kedudukannya akan menjadi sama dengan kedudukan para kreditur lainnya yang bukan pemegang hak tanggungan yang tidak diutamakan pelunasan piutangnya dan para kreditur tersebut bersama-sama sebagai kreditur konkuren.

Pasal 1131 BW menegaskan tanggung jawab seseorang atas perikatan/utangnya, yaitu segala kebendaan si berutang baik yang bergerak maupun yang tidak bergerak, baik yang sudah ada maupun yang baru akan ada di kemudian hari, menjadi tanggungan untuk segala perikatan seseorang. Kebendaan tersebut menjadi jaminan bersama bagi semua orang yang menghutang kepadanya, pendapatan penjualan benda-benda itu dibagi menurut kesimbangan, yaitu menurut besar kecilnya piutang masing-masing, kecuali apabila diantara para yang berpiutang tersebut ada alasan yang sah untuk didahulukan (sebagai kreditur Preferen).

${ }^{15}$ Rachmadi Usman, 1999, Pasal-Pasal Tentang Hak Tanggungan atas Tanah, Djambatan, Jakarta, hal 125-126.
Pada perjanjian kredit, hak tanggungan memilliki posisi yang penting terutama dalam pengamanan apabila kredit yang diberikan mengalami kegagalan atau terjadinya wanprestasi. Dengan hapusnya hak tanggungan karena hapusnya hak atas tanah yang dibebani hak tanggungan, maka kreditur tidak lagi berkedudukan sebagai kreditor preferen serta memiliki hak jaminan yang kuat dan kepastian hukum akan diprioritaskan pelunasan piutangnya oleh debitur.

Sebagai pihak yang nantinya akan dirugikan akibat hapusnya hak atas tanah yang diagunkan, kreditor dapat melakukan upaya. Upaya tersebut dilakukan dengan pencantuman kuasa dalam APHT atas tanah yang bersangkutan, dimana hal tersebut telah dimungkinkan dalam Pasal 11 ayat (2) huruf d Undang-Undang Hak Tanggungan, yaitu janji yang memberikan kewenangan kepada pemegang Hak Tanggungan untuk menyelamatkan objek hak tanggungan, jika hal itu diperlukan untuk pelaksanaan eksekusi atau untuk mencegah menjadi hapusnya atau dibatalkannya hak yang menjadi objek hak tanggungan karena tidak dipenuhi atau dilanggarnya ketentuan undang-undang. Dengan adanya klausula tersebut, kreditor dapat melindungi objek jaminan dan memastikan bahwa dirinya yang pertama akan mendapat pemenuhan piutang.

Hapusnya status hak atas tanah yang menjadi objek hak tanggungan menyebabkan hapusnya hak tanggungan. Setelah hak tanggungan ini hapus, demi ketertiban administrasi dilakukan pencoretan atau roya hak tanggungan. Pencoretan hak tanggungan ini tidak mempunyai pengaruh hukum terhadap hak tanggungan yang bersangkutan yang sudah dihapus. Roya atau pencatatan hapusnya hak tanggungan diatur dalam Pasal 22 UndangUndang Hak Tanggungan. Pencatatan hapusnya 
hak tanggungan tersebut dilakukan oleh Kepala Kantor Pertanahan dengan mencoret catatan adanya hak tanggungan pada buku tanah dan sertipikat objek yang dijadikan jaminan, dalam waktu tujuh hari kerja terhitung sejak diterimanya permohonan roya dari pihak yang berkepentingan.

Mengenai hak tanggungan yang hapus karena 'hak yang dibebani hapus' pendaftaran hapusnya dilakukan berdasarkan keputusan pejabat yang berwenang mengenai pembatalan atau pencabutan hak yang bersangkutan. Pendaftaran hapusnya hak tanggungan ini dilakukan oleh Kepala Kantor Pertanahan karena jabatannya (Pasal 122 Peraturan Menteri Negara Agraria No. 3 Tahun 1997). Selanjutnya dalam pasal 123 Peraturan Menteri Negara Agraria tersebut diatur pendaftaran hapusnya hak tanggungan yang dilakukan dengan : 1) mencoret catatan mengenai adanya Hak Tanggungan di dalam buku tanah hak yang dibebani dan sertipikatnya; 2) mencantumkan catatan di dalam buku tanah Hak Tanggungan bahwa Hak Tanggungan itu sudah hapus dan buku tanah hak tanggungan tidak berlaku lagi; 3) menarik sertipikat hak tanggungan dan mencantumkan catatan bahwa hak tanggungan teresbut sudah hapus dan sertipikat tersebut tidak berlaku lagi, apabila sertipikat hak tanggungan tersebut tidak dapat ditarik, dalam buku tanah Hak Tanggungan dicantumkan catatan bahwa sertipikat tersebut tidak dapat ditarik.

\section{Penutup}

\subsection{Simpulan}

Status hukum hak atas tanah (Hak Guna Bangunan) di atas tanah Hak Pengelolaan yang ijin pemanfaatan tanahnya telah dicabut oleh Gubernur, tidak lagi berstatus sebagai Hak Guna Bangunan, dengan kata lain hak atas tanahnya menjadi hapus. Dicabutnya surat keputusan pemanfaatan tanah hak pengelolaan oleh Gubernur merupakan wujud dari pengawasan dan kontrol yang dilakukan sebagai pemegang Hak Pengelolaan. Kewenangan mencabut ini didasarkan pada delegasi wewenang bidang pertanahan dari Pemerintah Pusat sebagai konsekuensi Hak Menguasai Negara atas Tanah. Atas dasar pencabutan ijin pemanfaatan tanah ini Gubernur dapat mengusulkan kepada Kepala Badan Pertanahan Provinsi untuk membatalkan sertipikat Hak Guna Bangunan yang memberi konsekuensi yuridis pada hapusnya Hak Guna Bangunan di atas tanah Hak Pengelolaan

Akibat hukum dari pembebanan Hak Tanggungan atas Hak Guna Bangunan di atas tanah Hak Pengelolaan yang ijin pemanfaatan tanahnya telah dicabut oleh Gubernur menyebabkan Hak Tanggungan menjadi hapus. Karena dengan hapusnya hak atas tanah maka berakibat pada segala perbuatan hukum yang dilakukan termasuk pembebanan hak tanggungan. Perjanjian kredit masih tetap ada, hanya saja kreditor tidak lagi memiliki hak istimewa sebagai pemegang hak tanggungan atas jaminan yang diberikan berupa hak atas tanah tersebut.

\subsection{Saran}

1. Kepada Pemerintah Provinsi (Gubernur) sebagai pemegang Hak Pengelolaan agar lebih memahami esensi dari pemberian hak pengelolaan atas tanah kepada pihak ketiga. Kontrol dan pengawasan terhadap pemberian ijin pemanfaatan tanah sangat diperlukan untuk meminimalisir terjadinya penyimpangan yang nantinya dapat merugikan Pemerintah dan juga rakyat.

$$
\text { Kepada Pemegang Hak atas }
$$
Tanah dapat mengajukan upaya 
hukum atas pembatalan (pencabutan

ijin) yang dilakukan oleh Pemegang

Hak Pangelolaan. Upaya hukum ini

didasarkan pada prinsip persamaan

hukum dan perlindungan hukum

yang seimbang antara Negara

(instansi Pemerintah selaku

pemegang Hak Pengelolaan) dengan

warga negara (equality before the

law).

2. Kepada Bank sebagai kreditur harus memastikan bahwa telah terpenuhinya syarat berupa persetujuan dari pemegang hak pengelolaan sebagai persetujuan pengalihan apabila terjadi wanprestasi. Selain itu dapat mencantumkan klausula dalam APHT, yaitu janji yang memberikan kewenangan pada kreditor untuk melindungi objek jaminan dan memastikan bahwa dirinya yang pertama akan mendapat pemenuhan piutang sebagaimana ditentukan dalam Undang-Undang Hak Tanggungan.

\section{Daftar Bacaan}

\section{A. Buku}

Badrulzaman, Mariam Darus, 1987, Bab-bab Tentang Creditverband, Gadai dan Fiduciam cetakan IV, Alumni Bandung.

Hutagalung,Arie Sukanti dan Markus Gunawan, 2008, Kewenangan Pemerintah di Bidang Pertanahan, PT. Raja Grafindo Persada, Jakarta.

Ibrahim, Johannes, 2004, Cross Default dan Cross Collateral sebagai Upaya Penyelesaian Kredit Bermasalah, PT Refika Aditama, Bandung.

Indroharto, 1995, Perbuatan Pemerintahan Menurut Hukum Publik dan Hukum Perdata, LPP-HAN, Jakarta.

Rahman, Hassanudin, 1998, Aspek-Aspek Hukum Pemberian Kredit Perbankan di Indonesia, Citra Aditya Bakti, Bandung.

Soerodjo, Irawan, 2014, Hukum Pertanahan Hak Pengelolaan atas Tanah, LaksBang Mediatama, Yogyakarta.

Sofwan, Sri Soedewi Masjchoen, 1981, Hukum Perdata, Hak Jaminan Atas Tanah, Liberty, Yogyakarta.

Subekti, 1996, Hukum Perjanjian, Intermasa, Jakarta.

Supramono, Gatot, 1996, Perbankan dan Masalah Kredit Suatu Tinjauan Yuridis, Djambatan, Jakarta.

Supriyadi, 2010, Aspek Hukum Tanah Aset Daerah Menemukan Keadilan, Kemanfaatan, dan Kepastian atas Eksistensi Tanah Aset Daerah, PT. Prestasi Pustakaraya, Jakarta.

Sutedi, Adrian, 2010, Hukum Hak Tanggungan, Sinar Grafika, Jakarta.

Suyatno, Thomas, 1993, Dasar-Dasar Hukum Perkreditan Edisi Ketiga, Gramedia Pustaka Utama, Jakarta.

Usman, Rachmadi 1999, Pasal-Pasal Tentang Hak Tanggungan atas Tanah, Djambatan, Jakarta.

\section{B. Tesis}

Caroline Syah, 2012, Perlindungan Hukum Bagi Pemberi Hak Tanggungan, Pemegang Hak Tanggungan, dan Pihak Ketiga dalam Kaitannya Dengan Keabsahan Akta Pemberian Hak Tanggungan (Analisis Putusan Mahkamah Agung Republik Indonesia No. 1910 K/PDT/2005, Tesis, Fakultas Hukum Universitas Indonesia Program Studi Magister Kenotariatan Depok.

\section{Internet}


Bung Pokrol, Batalnya Suatu Perjanjian, Hukum online, http: hukumonline.com ****** 